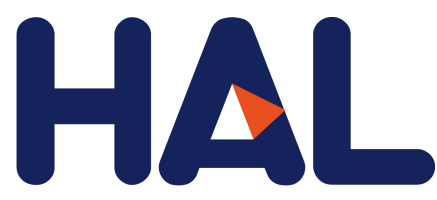

archives-ouvertes

\title{
Panoploscelis scudderi Beier, 1950 and Gnathoclita vorax (Stoll, 1813): two katydids with unusual acoustic, reproductive and defense behaviors (Orthoptera, Pseudophyllinae)
}

Sylvain Hugel

\section{To cite this version:}

Sylvain Hugel. Panoploscelis scudderi Beier, 1950 and Gnathoclita vorax (Stoll, 1813): two katydids with unusual acoustic, reproductive and defense behaviors (Orthoptera, Pseudophyllinae). Zoosystema, Museum Nationale d'Histoire Naturelle Paris, 2018, 40 (sp1), pp.327. 10.5252/zoosystema2019v41a17. hal-02349677

\section{HAL Id: hal-02349677 \\ https://hal.archives-ouvertes.fr/hal-02349677}

Submitted on 21 Jan 2021

HAL is a multi-disciplinary open access archive for the deposit and dissemination of scientific research documents, whether they are published or not. The documents may come from teaching and research institutions in France or abroad, or from public or private research centers.
L'archive ouverte pluridisciplinaire HAL, est destinée au dépôt et à la diffusion de documents scientifiques de niveau recherche, publiés ou non, émanant des établissements d'enseignement et de recherche français ou étrangers, des laboratoires publics ou privés. 


\title{
TITLE English
}

Panoploscelis scudderi Beier, 1950 and Gnathoclita vorax (Stoll, 1813): two katydids with unusual acoustic, reproductive and defense behaviors (Orthoptera, Pseudophyllinae).

\section{TITLE French}

Panoploscelis scudderi Beier, 1950 et Gnathoclita vorax (Stoll, 1813) : deux sauterelles aux comportements acoustiques, reproducteurs et de défenses remarquables (Orthoptera, Pseudophyllinae).

\section{RUNNING head}

Two katydids with unusual behaviors

\section{Sylvain HUGEL}

INCI, UPR 3212 CNRS, Université de Strasbourg,

5 rue Blaise Pascal, F-67000 Strasbourg (France)

hugels@inci-cnrs.unistra.fr

\begin{abstract}
Two species of Eucocconotini Beier, 1960 were collected during the "Our Planet Revisited, Mitaraka 2015” survey in the Mitaraka Mountains belonging to Tumuc-Humac mountain chain in French Guyana: Gnathoclita vorax (Stoll, 1813) and Panoploscelis scudderi Beier, 1950. Calling songs of both species are described for the first time, as well as the mandibular and tegminal protest signals from $P$. scudderi males and females. The structures involved in these signals are described and illustrated. The peculiar acoustic and mate guarding behaviors of Gnathoclita vorax are described and illustrated. The synonymy of Panoploscelis scudderi Beier, 1950 and Panoploscelis angusticauda Beier 1950 n. syn. is discussed and proposed, based on specimens reared from samples collected in Mitaraka.
\end{abstract}

\section{KEY WORDS}

Insecta, Orthoptera, Ensifera, Pseudophyllinae, mate guarding, acoustic communication, French Guyana

\section{RÉSUMÉ}

Deux espèces de Eucocconotini Beier, 1960 ont été collectées au cours de l'expédition "La planète revisitée, Mitaraka 2015” dans le massif du Mitaraka appartenant à la région des Tumuc-Humac en Guyane française: Gnathoclita vorax (Stoll, 1813) et Panoploscelis scudderi Beier, 1950. Les chants d'appel des deux espèces sont décrits pour la première fois, ainsi que les signaux de protestation que mâles et femelles de $P$. scudderi produisent avec leurs élytres et leurs mandibules. Les structures impliquées dans ces signaux sont décrites et illustrées. Les comportements acoustiques et de garde très particuliers de Gnathoclita vorax sont décrits et illustrés. La synonymie de Panoploscelis scudderi Beier, 1950 et Panoploscelis angusticauda Beier 1950 n. syn. est discutée et proposée en nous appuyant sur les spécimens élevés à partir des collectes au Mitaraka.

\section{MOTS CLÉS}

Insecte, Orthoptère, Ensifère, Pseudophyllinae, comportement de garde, communication acoustique, Guyane française

\section{INTRODUCTION}


Nine genera of Eucocconotini Beier, 1960 are currently known. Specimens belonging to two Eucocconotini genera have been collected during the "Our Planet Revisited, Mitaraka 2015" survey in the Mitaraka Mountains localized in the southwestern-most corner of French Guiana. With three weeks one site, such relatively long survey not only aims at performing large scale sampling, it also allows spending time for biological observations of the species in their environment. Among the numerous observations, video and sound records of Orthoptera made during this survey, the ones related to the two species of Eucocconotini observed in Mitaraka are of peculiar interest, and are the object of the present article.

\section{MATERIAL AND METHODS}

\section{MATERIAL EXAMINED}

Samples collected. The material used in this work was collected during the "Our Planet Revisited, Mitaraka 2015” survey in the Mitaraka Mountains (22/02/2015 to 11/03/2015). This large-scale biodiversity survey was co-organized by the French Museum of Natural History and the NGO Pro-Natura international. Mitaraka Mountains are a little known area sitting in the southwestern-most corner of French Guiana bordering Surinam and Brazil. Mitaraka belongs to the Tumuc-Humac mountain chain, extending east in Amapa region and west in southern Surinam. Most of the area is covered by a tropical lowland rain forest from which few inselbergs and hills emerge. All specimens collected during the survey are deposited in MNHN collections.

Museum specimens. High quality pictures of Panoploscelis scudderi and Panoploscelis angusticauda holotypes were kindly provided by Dr. Harald Bruckner, Naturhistorisches Museum, Wien, Austria. High quality pictures of Panoploscelis scudderi allotype were kindly provided by Anna Liana and Przemysław Szymroszczyk, Museum and Institute of Zoology, Polish Academy of Sciences, Warsaw, Poland.

SAMPLING METHODS

All Panoploscelis and Gnathoclita specimens were collected during night hours, either by sight with a headlamp or thanks to their conspicuous acoustic behavior. All specimens of these species have been collected by the author; both species were absent from the numerous traps used by the survey team.

\section{ACOUSTIC ANALYSES AND TERMINOLOGY}

Sound recordings were either directly performed on the field, or in studio-like conditions. Sounds were acquired with an Audiotechnica AT822 stereo microphone, on a NIKON D5200 camera (sampling rate: $96 \mathrm{kHz}$ ) with a red illumination (to follow the insect behaviour). Song analysis has been performed with Clampfit 10.2 software. Song recordings are deposited in both S.H. and MNHN acoustic databases. Acoustic terminology is from Stumpner et al. 2013.

\section{RESULTS}

\section{Panoploscelis scudderi Beier, 1950.}

Panoploscelis scudderi Beier, 1950: 112.

TYPE MATERIAL. - Coll. Br. V. W. [Printed], Rio Branco, Peru [manuscript; in reality Brazil], Staudinger [manuscript]; 24.875 [manuscript]; Type [printed, red label], Panoploscelis armata Scudd. [manuscript] determ. Karny [printed]; Panoploscelis scudderi n. sp. Type $\lesssim$ [manuscript]; NHM, Wien, Austria, high quality pictures examined. — Type [printed, red label]; Natt: 12; Rio-Negro [manuscript]; Panoploscelis armata Scudd. [manuscript]; 
Panoploscelis angusticauda n. sp. Type ! $q$ [manuscript] det. Beier [printed], NHM, Wien, Austria, high quality pictures examined.

TYPE LOCALITY. — Rio Branco, Brasil.

OTHER MATERIAL EXAMINED. - Planète revisitée Guyane 2015, Monts Tumuc-Humac, Massif du Mitaraka, Layon D, 54.4509 O 2.2357 N 280m - 54.4517 O 2.2338 N 293m, 23 II10 III 2015, nuit, 1 ふૈ, 1 q MNHN; Planète revisitée Guyane 2015, Monts Tumuc-Humac, Massif du Mitaraka, vers sommet en Cloche, 54.4541 O 2.2349 N 370m - 54.4646 O 2.2329 N 470m, 23 II-10 III 2015, nuit, 1 o, MNHN. These specimens were reared, and F1-F2 generations were also examined for the present work to assess the variability of diagnostic characters.

DISTRIBUTION. — South America: North Brazil, Guyana, French Guyana.

\section{Panoploscelis scudderi Beier, 1950 and Panoploscelis angusticauda Beier, 1950}

Both species were described in the same article by Max Beier (1950). P. scudderi was described from North Brazil after a single subaldult male and $P$. angusticauda from Northwestern Brazil after a single adult female. Since holotypes of both species are from different genders and one is immature, only non-sexual characters present in both adults and immatures might help to distinguish $P$. scudderi and $P$. angusticauda, should these really be different. We examined unpublished high quality pictures of both holotype specimens, and the only character that may be used to distinguish them as separate species is the shape of the epiproct: more rounded in $P$. angusticauda holotype and angulose in P. scudderi holotype.

Our colony of Panoploscelis from Mitaraka display quite variable shape of epiproct in both males and females (Fig. 1C), making impossible to rely on this character to conclude whether $P$. scudderi and $P$. angusticauda holotypes really belong to different species.

With the currently available characters and since characters previously used to distinguish the species are quite variable in our colony reared form Mitaraka samples, we found no support that $P$. angusticauda and $P$. scudderi are different species and consider at this stage that:

Panoploscelis scudderi Beier, 1950 = Panoploscelis angusticauda Beier, 1950 n. syn.

Interestingly, one additional adult female was included in the original description of P. scudderi as female allotype. This female is mentioned from "Stettin" collections by Max Beier (1950) and is now in Warsaw/Lomna. This female is from a distinct locality (British Guyana). Beier probably considered this female as conspecific with the male holotype of $P$. scudderi since both display an angulose epiproct. Although $P$. scudderi holotype cannot be recognized as different from $P$. angusticauda holotype, that female might belong to another yet unnamed species. The epiproct of this female falls within the range of variation of our Mitaraka specimens (similar to Fig. 1C1) and does not allow to recognize another species. As pointed by Beier $(1950,1960)$, this female allotype has a wide ovipositor, 5 times longer than wide, lanceolate, whereas $P$. angusticauda holotype has more slender ovipositor, 6.5 times longer than wide, with regularly converging margins. Females in our colony of Panoploscelis from Mitaraka have very variable ovipositor shape and length (Fig. 1B), and ovipositor of the female considered by Beier as $P$. scudderi allotype is only slightly less slender than extreme specimens in our colony, raising doubts on reliability of this character. Interestingly, the left forewing of this specimen has 5-6 transverse tubercle-bearing veins on the mirror whereas $P$. angusticauda female holotype has 3-4 tubercle-bearing veins on the mirror. In addition, the shape of the mirror of that female considered by Beier as $P$. scudderi allotype is very unusual, much narrow distally, and tubercle bearing veins as well as large cells occur outside of the mirror area and might suggest an abnormality. Our colony of Panoploscelis from Mitaraka typically display 3-4 tubercle-bearing veins on the mirror (Fig. 1A1, Fig. 3A), but a significant proportion display variation (2-5 veins, Fig. 1A) indicating that this character might not be very stable and/or subject to abnormalities. 
At this stage, it is difficult to define whether this specimen corresponds to Panoploscelis scudderi with abnormal wings or to another yet unnamed species.

Panoploscelis scudderi Beier, 1950

\section{Description of the male}

Head. Fig. 2A-B. All as in female. Fastigium verticis spine-shaped, reaching antennal sockets. Fastigium frontis spine-shaped. Carina lateralis interna distinct at the basis, carina lateralis externa complete. Scapus with one distal inner spine and one distal dorsal tubercle.

Thorax. Fig. 2B. Anterior margin with a distinct median tubercle; in addition to the two transverse sulci, sagittal sulci at least distinct at the level of posterior transverse sulcus (as in female); posterior margin broadly rounded with an inconspicuous median emargination of the rim. Metazona elevated. Legs. All as in female, anterior tibia and femora longer than mid tibia and femora. Fore femur (Fig 2C): distal spine of inner ventral margin perpendicular to femur axis; dorsally with 4-5 spines. Posterior femora dorsally with 5-7 spines (Fig. 2D); mid femora unarmed dorsally. Inner genicular lobe of fore femora unarmed. Wings. Left forewing shorter than right forewing (this very unusual asymmetry is possibly a generic character). Left mirror area triangular, right mirror somewhat oval. Anal field posterior margin of left forewing with a concavity; posterior margin of both forewing with an emargination distal to the anal field. File with ca. 66 teeth. Abdomen. Suranal distal margin variable, usually with an angle (as in female), sometimes very obtuse. Cercus short, stout, with a single inner ventral spine-shaped projection.

Subgenital plate broad at basis, moderately tapering distally; with a more or less rounded Vshaped emargination between the styli.

MEASUREMENTS. — See Table 1.

TABLE 1. Measurements of males of Panoploscelis scudderi (in mm).

L: length, W: width.

\begin{tabular}{|l|l|l|l|l|l|l|l|l|l|}
\hline Body & Pronotum & $\begin{array}{l}\text { Left } \\
\text { forewing }\end{array}$ & $\begin{array}{l}\text { Fore } \\
\text { tibia }\end{array}$ & $\begin{array}{l}\text { Mid } \\
\text { tibia }\end{array}$ & $\begin{array}{l}\text { Hind } \\
\text { tibia }\end{array}$ & $\begin{array}{l}\text { Fore } \\
\text { femur }\end{array}$ & $\begin{array}{l}\text { Mid } \\
\text { femur }\end{array}$ & $\begin{array}{l}\text { Hind } \\
\text { femur }\end{array}$ & $\begin{array}{l}\text { Hind } \\
\text { femur }\end{array}$ \\
\hline L & L & L & L & L & L & L & L & L & W \\
\hline $50-66$ & $13.5-15.5$ & $11-14$ & $\begin{array}{l}20.5- \\
23.5\end{array}$ & $20-21.5$ & $29-35.3$ & $18.5-23$ & $18-20.5$ & $28-32.5$ & $5-5.5$ \\
\hline
\end{tabular}

Female has been described under Panoploscelis scudderi and Panoploscelis angusticauda in Beier $(1950,1960)$. Variation in characters are illustrated Fig. 1. Forewings of a female specimen from Mitaraka are illustrated in Fig. 3A-B. Female forewings of $P$. scudderi lack the scraper lobe pointed by Montealegre-Z et al. (2003) in females of Panoplscelis specularis Beier, 1950.

Bioacoustics. Male call (Fig. 4). In rearing conditions, with many males and females together, the call of Panoploscelis scudderi males is very rarely heard. Single males sing only by night hours. At $24{ }^{\circ} \mathrm{C}$, the song is made of 3-12 verses repeated every $31.7 \pm 3.1 \mathrm{~s}$ (min: $18.44 \mathrm{~s}$; max: $43.60 \mathrm{~s}$ ). The first verse is usually softer than the subsequent ones. The duration of one verse is $7.5 \pm 0.6 \mathrm{~s}$ (min: $4.4 \mathrm{~s}$; max: $10.0 \mathrm{~s}$ ). Verses are made of $29.4 \pm 1.9$ phonatomes (min: 18; max: 34) repeated every $251 \pm 2 \mathrm{~ms}$ (min: $233 \mathrm{~ms}$; max $271 \mathrm{~ms}$ ). The duration of one phonatome is $60 \pm 2 \mathrm{~ms}$ (min: $30 \mathrm{~ms}$; max: $87 \mathrm{~ms}$ ). At $24^{\circ} \mathrm{C}$, a first peak was recorded at ca. $10.3-11.0 \mathrm{kHz}$, and a secondary broad peak was recorded at $30.5 \mathrm{kHz}$.

Isolated males seldom produce isolated verses (1-3 per nights). 
Female call. In our initial rearing conditions (30 adult pairs in a $0.3 \mathrm{~m}^{3}$ cage at $24^{\circ} \mathrm{C}$ by night), we failed to record any call from females (at F3 generation, a total of 50 adult females have been reared). Since males only rarely sing in the same conditions, this lack of spontaneous calls might simply be linked to specimen density. Therefore at F4 generation, subadult males and females were separated and kept in isolation for 2 months after their last molting. Under these conditions, males were calling very frequently (at least one call every 10 min for 25 males together in a cage). We were nevertheless unable to record any song from females, even with overnight recordings (8 full night recordings). Since females may only respond to male call, we play-backed male calls (one call every $10 \mathrm{~min}$, during the whole night): no responses were recorded (two overnight recordings). We than checked whether females respond to males during the mating process: we put virgin females together with males in one single empty cage and imaged/recorded them during the whole night. Under these conditions, all females mated within the first 30 minutes, and neither males nor females produced any song (supplementary video 3).

These data suggest that call of $P$. scudderi females is not required in the reproductive behavior of that species. It cannot be ruled out that $P$. scudderi females do not call at all since the only tegminal sounds we recorded were produced as protest signals.

Interstingly, P. scudderi females lack the scraper lobe pointed by Montealegre-Z et al. (2003) in $P$. specularis (Fig. 3A). This might speculatively suggest that intraspecific female signaling might be less developed in $P$. scudderi.

Male and female protest signals. Both males and females respond to air puff, water spraying or simple touch by lifting their forelegs and repeated protest signals (Fig. 3C). These protest signals are produced by tegminal stridulatory organs as well as mandibles/labrum. At $24{ }^{\circ} \mathrm{C}$, male tegminal protest signal (Fig. 5AB) is made of phonatomes isolated or grouped (2-3) repeated every $420 \pm 78 \mathrm{~ms}$ (min: $108 \mathrm{~ms}$; max: $1335 \mathrm{~ms}$ ). The frequency peaks at $9.4 \mathrm{kHz}$, a frequency significantly lower than male call. At $24^{\circ} \mathrm{C}$, female tegminal protest signal (Fig. 5CD) is made of verses repeated every 348 $\pm 56 \mathrm{~ms}$ (min: $246 \mathrm{~ms}$; max: $836 \mathrm{~ms}$ ). Verses are made of $5 \pm 1$ phonatomes (min: 2; max: 12) of irregular duration and spacing. The power spectrum of female tegminal protest is broad and displays a double peak: one at $10 \mathrm{kHz}$ and another at $14 \mathrm{kHz}$. Male and female mandibular protest signal (Fig. 6, Supplementary video 1). Mandibular protest signals are similar in males and females. These are the first protest signals produced when a specimen is stimulated, the tegminal signal requiring more stimulation. This signal has two phases: the first phase is produced while opening the mandibles and up lifting the labrum by clypeus retraction, the second is produced by the return to the resting state. The total duration of a cycle is very variable, lasting ca. $0.5 \mathrm{~s}$, with a first phase usually longer than the second one. These signals are repeated every $2.3 \pm 0.2 \mathrm{~s}$ (min: 0.7 ; max: 3.6). The power spectrum of this signal displays a broad peak between $10.3 \mathrm{kHz}$ and $14.6 \mathrm{kHz}$

Protest signals appear broader and emitted at lower frequencies than male call. This might speculatively be linked to the correlation between signal valence and signal frequency in intraspecific communication of some rodent species were lower frequencies are associated to unpleasant situations (Knuston et al. 2002).

\section{Comparison of $P$. specularis and $P$. scudderi male call.}

Whereas the call of $P$. specularis males is made of two phonatomes separated by $\sim 130 \mathrm{~ms}$ and regularly repeated every $\sim 3 \mathrm{~s}$, the song of $P$. scudderi is more complex in structure, with phonatomes organized in verses (see above). Alternatively, since $P$. scudderi sometimes produces isolated verses, one cannot rule out that $P$. specularis could do the same, and the full 
call of this species with organized verses may speculatively have been missed. The frequency of the maximally intense peak is relatively lower in $P$. scudderi than in $P$. specularis $(10-11$ kHz vs. $11-13 \mathrm{kHz})$.

\section{Gnathoclita vorax (Stoll, 1813)}

Gryllus (Acheta) vorax Stoll, 1813: Plate 4c, Fig 19, 20.

Gryllus (Gnathoclita) vorax De Haan, 1843: 208.

TYPE MATERIAL. - lost?

TYPE LOCALITY. - America

OTHER MATERIAL EXAMINED. - Planète revisitée Guyane 2015, Monts Tumuc-Humac, Massif du Mitaraka, 54.450137 O 2.233883 N (GF DZ) 315 m ; 23 II - 10 III 2015 nuit 1へ; Planète revisitée Guyane 2015, Monts Tumuc-Humac, Massif du Mitaraka, Layon D, 54.4509 O 2.2357 N 280m - 54.4517 O 2.2338 N 293m, 23 II-10 III 2015, nuit 1 ô, 1 o ; Planète revisitée Guyane 2015, Monts Tumuc-Humac, Massif du Mitaraka, vers sommet en Cloche, 54.4541 O 2.2349 N 370m - 54.4646 O 2.2329 N 470m, 23 II-10 III 2015, nuit, 1 ô, 1 q, all MNHN.

DISTRIBUTION. - Surinam, Guyana, Brazil North [Cigliano et al, OSF, 2018], French Guyana.

Males and females of this species have been comprehensively redescribed (Willemse 1954, Beier 1960, De Jong 1971).

Stridulatory apparatus (Fig. 7D-E). Left FW mirror infuscated, with no concavity, oval shaped except the anterior proximal angle; about 2 times as high (maximal height) as wide (maximal width). File with ca. 101 lamellar teeth (Fig. 7E).

Bioacoustics (Fig. 7A-C, Supplementary video 2). Gnathoclita vorax sings by night hours, from the undergrowth from plant-made cavities. The call consists of long ( $>1 \mathrm{~min}$ ) relatively regular repetitions of syllables. At $26^{\circ} \mathrm{C}$, syllables are repeated every $3.818 \pm 0.625$ s (syllable duration: $50.8 \pm 4.3 \mathrm{~ms}$ ). The frequency peaks between $8750-8900 \mathrm{~Hz}$.

Comparison of G. vorax and G. sodalis Brunner von Wattenwyl, 1895 male call.

The call of $G$. sodalis is made of phonatomes repeated every 180-480 ms, depending on the temperature (Montealegre-Z \& Morris 1999) whereas G. vorax phonatomes are repeated every $\sim 4$ s. The call of $G$. sodalis peaks at about $15-16 \mathrm{kHz}$, about twice the frequency of $G$. vorax peak (Montealegre-Z \& Morris 1999). Interstingly, in addition to acoustic communication, $G$. sodalis males use tremulatory vibration to communicate with other males and females (De Souza et al 2011). This tremulatory behavior may not occur in G. vorax since males of this species sing in a very narrow environment (see below).

\section{Guarding behavior of Gnathoclita vorax}

A total of five males of Gnathoclita vorax were observed during the Mitaraka survey in 2015. All these observations occurred late by night hours (11 pm - $2 \mathrm{am})$. These males were sheltering in narrow tube-shaped hollow plant sections, their head facing the aperture of the cavity (Fig. 8A1). The diameter of these shelters was hardly larger than a male's head, preventing turn overs (Fig. 7D, 8). The shelter of all but one specimen was within hollow dead stems of Astrocaryum sp.. These observations are in line with a previous report of Gnathoclita vorax singing from within Gadua sp. bamboo stems (Naskrecki, 2008). 
Three of the five males observed were located owing to their loud syllables repeated every $5 \mathrm{~s}$ (Fig. 7A-C). These males were stridulating alone within their shelter, their antennae protruding from the entrance.

The two other males were found owing to their conspicuous antennae protruding from the aperture. None were stridulating. In both cases, an adult female was localized at the bottom of the tube-shaped shelter, behind the male which blocked the entrance (Fig. 8A2). None of the females had a spermatophore attached.

These specimens were kept separated for one week, and subsequently placed altogether in a large cage containing wood-made tube-shaped shelters of similar measurements to those observed in the field. Every morning, the localization of the females was checked. During the five first days together with the males, both females were observed as in the field: at the bottom of the shelter, a male blocking the entrance. Unfortunately, we have not been able to observe whether the female entered the shelter after mating, and whether the male was actively driving it. After five days, both specimens were forced out the shelter; only males returned to the shelter during the subsequent days and restarted to stridulate during nights.

These observations suggest that males of Gnathoclitha vorax display a form of mate guarding. Such a behavior was never formally observed in Tettigoniidae (Gwynne 2001), although a possible type of male guarding behavior was recently reported in Oncodopus and Colossopus (Unal \& Beccaloni, 2017).

The function of mate guarding has extensively been discussed in Grylloidea (Simmons 1990; Sakaluk 1991; Hockham \& Vahed 1997; Bateman \& Macfadyen 1999; Wynn \& Vahed 2004; Bussiere et al. 2006; Parker 2009; Parker \& Vahed 2009) and this behavior was shown to prevent the female from removing the spermatophore of a Gryllidae species (Hockham \& Wahed 1997). Since females had no spermatophore attached within the shelter, the mate guarding of Gnathoclitha vorax was rather recalling the burrow sharing occurring in some Grylloidea, such as Gryllus campestris (Rodriguez-Munoz et al 2011). In this latter species, the burrow sharing was shown to protect from predation and increase mating of paired males).

\section{Acknowledgements}

I acknowledge Harald Bruckner, Naturhistorisches Museum, Wien, Austria for providing high quality pictures of Panoploscelis holotypes and Anna Liana and Przemysław Szymroszczyk, Museum and Institute of Zoology, Polish Academy of Sciences, Warsaw, Poland for providing high quality pictures of Panoploscelis scudderi allotype. All the material examined for this work was collected by the author during the "Our Planet Reviewed" Guyane-2015 expedition in the Mitaraka range, in the core area of the French Guiana Amazonian Park, organized by the MNHN and Pro-Natura international. The expedition was funded by the European Regional Development Fund (ERDF), the Conseil régional de Guyane, the Conseil général de Guyane, the Direction de l'Environnement, de l'Aménagement et du Logement and by the Ministère de l'Éducation nationale, de l'Enseignement supérieur et de la Recherche. It was realized in collaboration with the Parc amazonien de Guyane and the Société entomologique AntillesGuyane. I acknowledge Fernando Montealegre-Z and David Rentz for their constructive comments on the manuscript.

\section{REFERENCES}

Bateman P.W. \& MacFadyen D.N. 1999. - Mate guarding in the cricket Gryllodes sigillatus: influence of multiple potential partners. Ethology 105:949-957. 
Beier M. 1950. - Das Genus Panoploscelis Scudder (Orthot.-Pseudophyllinae). Proceedings of the 8th International Congress of Entomology, Stockholm, 1948. 111-115.

Beier M. 1960. — Orthoptera Tettigoniidae (Pseudophyllinae II). In: Mertens, R., Hennig, W. \& Wermuth, H. (Eds.), Das Tierreich. 74, Walter de Gruyter \& Co., Berlin, pp. 396.

Bussiere L.F. Hunt J., Jennions M.D. \& Brooks R. 2006. — Sexual conflict and cryptic female choice in the black field cricket, Teleogryllus commodus. Evolution 60:792-800.

Cigliano M.M., Braun H., Eades D.C. \& Otte D. - Orthoptera Species File. Version 5.0/5.0. 01/02/2018. <http://Orthoptera.SpeciesFile.org>.

de Haan W. 1843. - Bijdragen tot de kennis der Orthoptera. Temminck [Ed.] Verhandelingen over de Natuurlijke Geschiedenis der Nederlansche Overzeesche Bezittingen 19/20:208.

De Jong C. 1971. - Notes on the types of Gnathoclita vorax (Stoll) (Tettigoniidae, Pterophyllinae) Zoologische Mededelingen uitgegeven door het Rijksmuseum van Natuurlijke Historie te Leiden. 45(26):303-311.

De Souza L.R., Kasumovic M.M., Judge K.A. \& Morris GK. 2011. — Communicating male size by tremulatory vibration in a Columbian rainforest katydid, Gnathoclita sodalis (Orthoptera, Tettigoniidae). Behaviour 148, 341-357.

Hockham L.R. \& Vahed K. 1997. - The function of mate guarding in a field cricket (Orthoptera: Gryllidae; Teleogryllus natalensis Otte and Cade). J Insect Behav 10:247-256.

Gwynne D.T. 2001. - Katydids and Bush-Crickets: Reproductive Behavior and Evolution of the Tettigoniidae (Cornell Univ. Press, Ithaca, New York, 2001).

Knutson B., Burgdorf J. \& Panksepp J. 2002. - Ultrasonic vocalizations as indices of affective states in rats. Psychological Bulletin, 128(6), 961-977.

Montealegre-Z F. \& Morris G.K. 1999. - Songs and systematics of some Tettigoniidae from Columbia and Ecuador I. Pseudophyllinae (Orthoptera). Journal of Orthoptera Research 8: 163-236.

Montealegre-Z F., Guerra P.A. \& Morris G.K. 2003. - Panoploscelis specularis (Orthoptera: Tettigoniidae: Pseudophyllinae): extraordinary female sound generator, male description, male protest and calling signals. Journal of Orthoptera Research 12(2):173-181.

Naskrecki P. 2008. - Katydids of Selected Sites in the Konashen Community Owned Conservation Area (COCA), Southern Guyana. RAP Bulletin of Biological Assessment 25-30.

Sakaluk S.K. 1991. - Postcopulatory mate guarding in decorated crickets. Anim Behav 41:207-216.

Parker D.J. 2009. - Pre and postcopulatory mate choice in Platygryllus primiformis: cryptic female choice and sexual conflict. Biosci Horizons 2:161-171.

Parker D.J. \& Vahed K. 2010. - The intensity of pre- and post-copulatory mate guarding in relation to spermatophore transfer in the cricket Gryllus bimaculatus. Journal of Ethology 28:245-249.

Pascal O., Touroult J., Bouchet P. 2015. — Expédition “La Planète Revisitée” Guyane 20142015. Synthèse des premiers résultats. Muséum nationale d'Histoire naturelle; Pro-Natura International, $280 \mathrm{pp}$.

Rodriguez-Munoz R., Bretman A. \& Tregenza T. 2011. - Guarding Males Protect Females from Predation in a Wild Insect. Current Biology 21(20): 1716-1719.

Simmons L.W. 1990. - Postcopulatory guarding, female choice and the levels of gregarine infections in the field cricket, Gryllus bimaculatus. Behav Ecol Sociobiol 26:403-407.

Stumpner A., Dann A., Schink M., Gubert S. \& Hugel S. 2013. - True katydids (Pseudophyllinae) from Guadeloupe: Acoustic signals and functional considerations of song production. Journal of Insect Science 13(157), 1-16.

Ünal M. \& Beccaloni G.W. 2017. — Revision of the Madagascan genera Oncodopus Brongniart and Colossopus Saussure (Orthoptera: Tettigoniidae: Conocephalinae; Euconchophorini), with description of Malagasopus gen. nov. Zootaxa 4341(2):193-228

Willemse C. 1954. - Gnathoclita vorax (Stoll), a little known Pseudophyllid from Dutch Guiana (Orthoptera). Ano del Libertador Gral. San Martin, 1: 239-245. 
Wynn H. \& Vahed K. 2004. - Male Gryllus bimaculatus guard females to delay them from mating with rival males and to obtain repeated copulations. J Insect Behav 17:53-66.

\section{FIGURE LEGENDS}

Fig. 1. - Variations in characters used to distinguish Panoploscelis scudderi and Panoploscelis angusticauda females. The specimens pictured are breed from samples collected in Mitaraka (F1 and F2 generations). The frequent most condition is represented in the left panels. Specimens from Mitaraka display variations in: A, the number of tubercle-bearing veins; $\mathbf{B}$, the shape of ovipositor in side view (holotype of $P$. angusticauda display the same shape of ovipositor as illustrated in B2); C, the shape of epiproct hind margin (male juvenile holotype of $P$. scudderi display the same shape of epiproct hind margin as illustrated in C5; in $P$. angusticauda, the hind margin is somehow as in C2). Scale bars: $10 \mathrm{~mm}$.

Fig. 2. - Male of Panoploscelis scudderi, after a specimen collected in Mitaraka. A, face in front view; B, Head and pronotum in dorsal view; C, right fore femur in front view. Note that the distal most ventral anterior spine is on the axis of the picture; $\mathbf{D}$, hind femur in side view; $\mathbf{E}$, apex of the abdomen in dorsal view; $\mathbf{F}$, cercus in dorsal view; $\mathbf{G}$, subgenital plate in ventral view. Scale bars: A-E, G: $10 \mathrm{~mm}$; F: $1 \mathrm{~mm}$.

Fig. 3. - Female of Panoploscelis scudderi, after a specimen collected in Mitaraka. A, forewings in dorsal view; $\mathbf{B}$, detail of forewings in dorsal view; $\mathbf{C}$, defensive position. Scale bars: A: $10 \mathrm{~mm}$; B: $5 \mathrm{~m}$.

Fig. 4. - Male of Panoploscelis scudderi, call and stridulatory apparatus. A-C, call of a wild male in studio conditions at $24^{\circ} \mathrm{C}$ after a specimen collected in Mitaraka; $\mathbf{E}$, male forewings in dorsal view; $\mathbf{F}$, file in ventral view.

Fig. 5. - Tegminal protest signals of Panoploscelis scudderi. A, B, male; C, D, female. All from wild specimens in studio conditions at $24^{\circ} \mathrm{C}$

Fig. 6. - Mandibular protest signals of Panoploscelis scudderi. A-C, mandibular protest signals produced by a F2 adult female. $\mathbf{D}$, pictures corresponding to the time points given in $\mathrm{C}$ illustrating the motion of mandibles, clypeus and labrum; E, right mandible (note the area with tubercles in E2; F, clypeus and labrum, inner view. Scale bars: $1 \mathrm{~mm}$.

Fig. 7. - Call of Gnathoclita vorax. A-C, Field recording of a male calling from a cavity $\left(26^{\circ} \mathrm{C}\right)$. $\mathrm{D}$, male stridulatory apparatus in dorsal view; E, male file in ventral view. Scale bar: $\mathrm{D}: 5 \mathrm{~mm}$; E: $2.5 \mathrm{~mm}$.

Fig. 8. - Shelters of Gnathoclita vorax in the field. A1, the face of a male in visible within a hollow shaft of Actrocaryum leaf, antennae protruding from the entrance. A2, when an aperture is made on the shaft, a female is visible behind the male (at the time of the picture, the male was already collected); $\mathbf{B}$, entrance of a shelter (male removed); $\mathbf{C}$, disturbed male escaping from the shelter; $\mathbf{D}$, picture of the male singing in A-C during the call. 